\title{
A comparative study of India and Australia open access repositories in open DOAR
}

\author{
Alekha Karadia ${ }^{*}$, Jyotshna Sahoo ${ }^{2}$ \\ ${ }^{1}$ Research Scholar, ${ }^{2}$ Associate Professor, Dept. of Library\& Information Science, Khallikote University, Berhampur, Ganjam, Odisha, India \\ *Corresponding Author: Alekha Karadia \\ Email: alekh98@gmail.com

\begin{abstract}
An open access repository or open archive is a digital platform that holds research output and provides free, immediate and permanent access to research results for anyone to use, download and distribute. To facilitate open access such repositories must be interoperable according to the Open Archives Initiative Protocol for Metadata Harvesting (OAI-PMH). Search engines harvest the content of open access repositories, constructing a database of worldwide, free of charge available research. OpenDOAR is the quality-assured, global Directory of Open Access Repositories. Its repositories provide free, open access to academic outputs and resources. This paper deals with Comparative analysis of India and Australia repositories listed in OpenDOAR in terms of their growth, type, operational status, content type, software, subject coverage, language and policies regarding content, submission, and preservation.
\end{abstract}

Keywords: Digital Repositories, Institutional Repositories, Open Access, OpenDOAR.

\section{Introduction}

Digital world to change the modes of Research scholarly communication. Digital Platform provides opportunity for the research scholars to work collaborative and effective ways to access resources and services. Growth of information Research scholars faces many problems and challenges to manage scholarly contents. Now days, Open Access Repositories create a platform online access to the all intellectual output of a particular organization.

Therefore institutional repositories are greater than ever day by day all over globe. Various organizations and institutions needs to be preserved, organized and disseminated their intellectual output. So, this is one of important reason for establishing an institutional repository in academic libraries and other government Organization. Open access repositories are the digital archives of scholarly literature deposited by their authors and it is called selfarchiving. These are established and managed to provide universal and free access to information in electronic format to increase and disseminate research output. (Verma \& Shukla, 2015).

\section{What is Open Access?}

There are many ways to define open access, but here is the definition given by the Budapest Open Access Initiative: "By "open access" to this literature, we mean its free availability on the public internet, permitting any users to read, download, copy, distribute, print, search, or link to the full texts of these articles, crawl them for indexing, pass them as data to software, or use them for any other lawful purpose, without financial, legal, or technical barriers other than those inseparable from gaining access to the internet itself. The only constraint on reproduction and distribution, and the only role for copyright in this domain, should be to give authors control over the integrity of their work and the right to be properly acknowledged and cited." (Graduate Institute Geneva, n.d)
1. Gold Open Access refers to OA delivered by journals. Some journals ask authors to pay a publication fee called APC (article-processing charge). Journals who do not charge any APC are sometimes called "platinum" Open Access.

2. Green Open Access or self-archiving refers to OA delivered by disciplinary or institutional repositories.

3. Bronze Open Access is used for articles that are made free to read on the publisher's website only without an explicit open license, and could, therefore, lose their OA status later.

\section{Review of Literature}

Anil Kumar and Kaur Manpreet (2020) the study explain Indian contribution towards the Open Access Repositories (OpenDOAR), which archives books, theses, journal articles, monographs, patents, learning objects, and unpublished papers since 2005-2019.

Maharana Bulu and Chakrabarti Abhijit (2019) the study presents Open Access Repositories in Library and Information Science available in OpenDOAR and evaluate the generic and technical features of them as per items, language, country, repository type, content, software, operational status, etc. open access digital repositories in the field of Library and Information Science available in OpenDOAR are indexed in English language and some of them are bilingual. It is also observed that open source softwares like Eprints and Dspace have been exploited in a large scale to create open access digital repositories in the field of Library and information Science indexed in OpenDOAR.

Mohammad Azim \& Nabi Hasan (2018). The study presents an analysis and explores the Indian repositories who have registered in the OpenDOAR and allows to access and download their data through OpenDOAR platform. The study also highlights the contributing Universities/Institutions and about the different types of software used to create their repositories. 
Sing, KP \& Vanita Khanchandani (2015) Study explores the of Indian contribution to Open Access Scholarly Publishing in Science and Technology indexed in DOAJ. The research highlights the various dimensions related to the open access scholarly communication in S\&T such as chronological growth, publisher-wise and subject-wise contributions, etc.

\section{Objectives of the study}

1. To find the India and Australia month and year growth of OA repositories registered at OpenDOAR and which country highest registered.

2. To identify the India and Australia types of repositories registered at OpenDOAR.

3. To assess India and Australia subject wise all the OA repositories registered at OpenDOAR.

4. To find the India and Australia most popular software platform used in OA Repositories registered at OpenDOAR.

5. To identify India and Australia the most commonly used language of content in such repositories registered at OpenDOAR.

\section{Scope of the study}

After browsing the URL (https://v2.sherpa.ac.uk/opendoar/) of the Directory of Open Access Repository (OpenDOAR), India and Australia have been retrieved and as per the objective of this study, India (98) and Australia (90) Open Access repositories have been selected to evaluate them. The study is limited to only Indian and Australia Open access Repository in the Directory of Open Access Repositories (OpenDOAR).

\section{Methodology}

The study is based on collected data from OpenDOAR as on 06 June 2021 . The collected data were carefully analyze and investigated on selected parameters like year-wise growth, use of IR software's, open access repositories types, content's languages, subjectwise India and Australia open access repositories.

\section{Analysis and Interpretation of Results}

Table 1: India and Australia type of organization open access repositories

\begin{tabular}{|l|c|c|}
\hline Type of Organization & India & Australia \\
\hline Aggregating & 05 & 00 \\
\hline Institutional & 84 & 79 \\
\hline Disciplinary & 08 & 07 \\
\hline Governmental & 01 & 04 \\
\hline & Total $=98$ & Total $=90$ \\
\hline
\end{tabular}

Table 1 show that majority of 84 Indian Open access Repositories and majority of 79 Australia Open access Repositories are Institutional and 08 Indian Open access Repositories 07 Australia Open access Repositories are Disciplinary, 04 Indian Open access Repositories and 00
Australia Open access Repositories are Aggregating and 01 Indian Open access Repositories and 04 Australia Open access Repositories are Governmental. Graph shows that Indian and Australia Open access Repositories are Institutional much more interested open Access Repositories, India and Australia Govt. Organization also registration in OpenDOAR. As compare to Australia Govt. organization India less then interested to registration OpenDOAR.

Table 2: India and Australia Open access Repositories Language of Content

\begin{tabular}{|l|c|c|}
\hline Language of Content & India & Australia \\
\hline English & & \\
\hline Hindi & 96 & 90 \\
\hline Marathi & 11 & 0 \\
\hline Gujurati & 4 & 0 \\
\hline Arabic & 3 & 0 \\
\hline Kannada & 2 & 0 \\
\hline Malayalam & 2 & 0 \\
\hline Bengali & 2 & 0 \\
\hline Other & 1 & 0 \\
\hline German & 3 & 0 \\
\hline Spanish & 0 & 1 \\
\hline Croatian & 0 & 1 \\
\hline Chinese & 0 & 1 \\
\hline
\end{tabular}

Table 2 This table shows the English Language is highest Content upload both India (96) and Australia (90) Open Access Repository. India Open Access Repository has Language of Content like Hindi Marathi Gujurati Arabic Kannada Malayalam Bengali,other and other hand Australia Open Access Repository has Language of Content like German, Spanish,Croatian,Chinese.

Table 3: India and Australia Software Platforms used for Open access Repositories

\begin{tabular}{|l|c|c|}
\hline Software Platforms & Australia & India \\
\hline Dspace & $21(22 \%)$ & $56(56 \%)$ \\
\hline E-prints & $12(12 \%)$ & $33(33 \%)$ \\
\hline VITAL & $7(7 \%)$ & $0(0 \%)$ \\
\hline Fez & $4(4 \%)$ & $0(0 \%)$ \\
\hline Digital Commons & $3(3 \%)$ & $0(0 \%)$ \\
\hline DigiTool & $3(3 \%)$ & $0(0 \%)$ \\
\hline Equella & $3(3 \%)$ & $0(0 \%)$ \\
\hline Pure & $3(3 \%)$ & $0(0 \%)$ \\
\hline Drupal & $2(2 \%)$ & $1(1 \%)$ \\
\hline Other & $40(41 \%)$ & $9(9 \%)$ \\
\hline Greenstone & $0(0 \%)$ & $1(1 \%)$ \\
\hline Total & $100 \%$ & $100 \%$ \\
\hline
\end{tabular}

Table 3 This table and graph show that number of organization both India (56\%) and Australia (22\%) developing Open access Repository through Dspace Open Sources Software, and also e-Print used for Open access Repository India (33\%) and Australia (12\%) Registered in 
OpenDOAR. India Used for Open access Repository software like Drupal, Greenstone, other and Australia Used for Open Access Repository software like VITAl, Fez, Digital Commons, DigiTool, Equella, Pure, Drupal, other. As Compared to India, Australia has more verity of software used for open access Repository.

Table 4: Growth of India and Australia open access repositories in OpenDOAR.

\begin{tabular}{|l|c|c|}
\hline Growth of OpenDOAR & India & Australia \\
\hline December 2005 & 2 & 6 \\
\hline August 2006 & 11 & 16 \\
\hline April 2007 & 12 & 41 \\
\hline December 2007 & 19 & 41 \\
\hline August 2008 & 22 & 48 \\
\hline April 2009 & 27 & 53 \\
\hline December 2009 & 28 & 54 \\
\hline August 2010 & 32 & 55 \\
\hline April 2011 & 38 & 57 \\
\hline December 2011 & 45 & 58 \\
\hline August 2012 & 47 & 59 \\
\hline April 2013 & 48 & 61 \\
\hline December 2013 & 60 & 62 \\
\hline August 2014 & 62 & 67 \\
\hline April 2015 & 67 & 68 \\
\hline December 2015 & 71 & 69 \\
\hline August 2016 & 73 & 71 \\
\hline April 2017 & 76 & 72 \\
\hline December 2017 & 79 & 73 \\
\hline August 2018 & 79 & 73 \\
\hline April 2019 & 84 & 78 \\
\hline December 2019 & 60 & 89 \\
\hline August 2020 & 93 & 90 \\
\hline May 2021 & 98 & 90 \\
\hline
\end{tabular}

Table 4 shows month and Year growth of India and Australia open access repositories in OpenDOAR. The study reveals that there are total 98 from India and 90 from Australia, May 2021. The study shows compare Australia more Awareness about registration OpenDOAR but India has highest registration Open Access Repository year of 2021.

Table 5: Subject of Content India and Australia open access repositories in OpenDOAR

\begin{tabular}{|l|c|c|}
\hline Subject of Content & India & Australia \\
\hline Multidisciplinary & 49 & 65 \\
\hline Technology General & 13 & 2 \\
\hline Health and Medicine & 12 & 10 \\
\hline $\begin{array}{l}\text { Mechanical Engineering and } \\
\text { Materials }\end{array}$ & 10 & 0 \\
\hline Computer and IT & 9 & 2 \\
\hline Biology and Biochemistry & 9 & 2 \\
\hline Science general & 8 & 4 \\
\hline Physics and Astronomy & 8 & 1 \\
\hline $\begin{array}{l}\text { Electrical and Electronic } \\
\text { Engineering }\end{array}$ & 7 & 0 \\
\hline
\end{tabular}

\begin{tabular}{|l|l|l|}
\hline $\begin{array}{l}\text { Agriculture,Food and } \\
\text { Veterinary }\end{array}$ & 7 & 3 \\
\hline $\begin{array}{l}\text { Library and Information } \\
\text { Science }\end{array}$ & 6 & 4 \\
\hline Ecology and Environment & 6 & 2 \\
\hline Civil Engineering & 5 & 1 \\
\hline Mathematics and Statistics & 5 & 1 \\
\hline Earth and Planetary Scienace & 4 & 0 \\
\hline Social Science General & 3 & 2 \\
\hline Management and Planning & 3 & 4 \\
\hline Arts and Humanities General & 2 & 5 \\
\hline Businees and Economics & 2 & 6 \\
\hline Psychology & 2 & 1 \\
\hline Architecture & 1 & 1 \\
\hline Language and Literature & 1 & 4 \\
\hline Education & 1 & 8 \\
\hline Law and politics & 1 & 5 \\
\hline Fine and Performing & 0 & 7 \\
\hline $\begin{array}{l}\text { Geography and Regional } \\
\text { studies }\end{array}$ & 0 & 5 \\
\hline History and Archaeology & 0 & 4 \\
\hline Philosophy and Religion & 0 & 4 \\
\hline $\begin{array}{l}\text { Chemistry and Chemical } \\
\text { technology }\end{array}$ & 0 & 1 \\
\hline
\end{tabular}

Table 5 Reveals that a large number India (49) and Australia (65) of Open Access repository are Multidisciplinary, India (12) and Australia (10) of Open Access repository are related to Health and Medicine and India (13) and Australia (2) of Open Access Repository are related to Technology General. India and Austrlia Open Access Repository are related to others subjects like Mechanical Engineering and Materials, Computer and IT, Biology and Biochemistry, Science general, Physics and Astronomy, Electrical and Electronic Engineering, Agriculture, Food and Veterinary, Library and Information Science, Ecology and Environment, Civil Engineering, Mathematics and Statistics, Earth and Planetary Scienace, Social Science, General, Economics, Psychology, Architecture, Language and Literature, Education, Law and politics, Fine and Performing, Geography and Regional studies, History and Archaeology, Philosophy and Religion, Chemistry and Chemical technology Management and Planning, Arts and Humanities General, Businees .

\section{Findings}

1. Growth of India and Australia open access repositories in OpenDOAR. The study reveals that there are total 98 from India and 90 from Australia, May 2021. The study shows compare Australia more Awareness about registration OpenDOAR but India has highest registration Open Access Repository year of 2021.

2. Indian and Australia Open access Repositories are Institutional much more interested open Access Repositories, India and Australia Govt. Organization

3. Large number India and Australia of Open Access repository are Multidisciplinary, India and Australia of Open Access repository are related to Health and 
Medicine and India and Australia of Open Access Repository are related to Technology General.

4. India (56\%) and Australia (22\%) developing Open access Repository through Dspace Open Sources Software, and also e-Print used for Open access Repository India (33\%) and Australia (12\%) Registered in OpenDOAR. India Used for Open access Repository software like Drupal, Greenstone, other and Australia Used for Open Access Repository software like VITAl, Fez, Digital Commons, DigiTool, Equella, Pure, Drupal, other. As Compared to India, Australia has more verity of software used for open access Repository.

5. English Language is highest Content upload both India (96) and Australia (90) Open Access Repository.

\section{Conclusion}

Lastly, This study conclude that there are 98 repositories from India and 90 repositories from Australia in OpenDOAR. In May 2021, a large number of Open Access Repository is included in OpenDOAR. Most of Open Access Repository is Institutional both India and Australia. Majority of India and Australia Open Access Repository contain contents in English language. India and Australia DSpace is popular software which is used in majority of Open access Repository. Large number of subject of content India and Australia of Open Access repository are Multidisciplinary.

\section{Conflict of Interest}

The authors declare that there are no conflicts of interest in this paper.

\section{Source of Funding}

None.

\section{References}

1. Verma, N. K. \& Shukla, A. (2015), Evaluating growth and development of open access repositories: a case study of OpenDOAR. In Proceedings of International Conference on "Knowledge Organisation in Academic Libraries" (pp. 59-69). LPA, New Delhi \& Manipal University, Jaipur.

2. Kumar A, Kaur M, Contribution of India to the Directory of Open Access Repositories (OpenDOAR ). Int J Libr Inf Stud. 2020;10(1) Jan-Mar, 2020 ISSN: 2231-4911.87-91p. retrieved from https://www.ijlis.org/articles/contribution-of-india-to-thedirectory-of-open-access-repositories.pdf

3. Maharana B, Chakrabarti A. LIS Open Access Institutional Digital Repositories in OpenDOAR: an appraisal". Libr Philos Pract (e-J). 2019;2757.

https://digitalcommons.unl.edu/libphilprac/2757

4. Azim M, Hasan N. (2018). Reflection of Indian Open Access Repositories in OpenDOAR: A Status Report. Retrived from https://www.researchgate.net/publication/327107580_Reflectio n_of_Indian_Open_Access_Repositories_in_OpenDOAR_A Status_Report

5. Jan R, Khan NA. (2010). Development of Disciplinary Repositories: A Case Study of Open DOAR. In 7th Convention PLANNER - 2010 (pp. 464-475). Ahmadabad, Gujarat: Inflibnet Centre. Retrieved May 20, 2018, from http://ir.inflibnet.ac.in:8080/ir/ViewerJS/\#../bitstream/1944/98 7/1/47.pdf

6. Sing, KP \& Vanita Khanchandani (2015). Indian Contribution to Open Access Scholarly Publishing in Science and Technology: A Critical Study of Directory of Open Access Journals(DOAJ). Library Herald. 2015;53(3):268-83.

7. Graduate Institute Geneva (n.d) What is Open Access .Retrive from https://libguides.graduateinstitute.ch/open-access/oadefinition

How to cite: Karadia A, Sahoo J. A comparative study of India and Australia open access repositories in open DOAR. IP Indian J Libr Sci Inf Technol. 2021;6(1):57-60. 